\title{
Immunization against tetanus
}

\author{
BY J. C. SURI* AND SYDNEY D. RUBBO \\ School of Bacteriology, University of Melbourne, Parkville, \\ Victoria, Australia
}

(Received 27 August 1960)

\section{INTRODUCTION}

In the prophylaxis of tetanus there are several questions of considerable clinical importance for which there are insufficient data to warrant definite answers. Among these may be mentioned: What is the duration of antitoxic immunity after the usual prophylactic dose of tetanus antitoxin (A.T.S.) in a person with previous experience of horse serum? Does the presence of heterologous antitoxin following passive immunization materially interfere with the primary immune response to tetanus toxoid?

According to Littlewood, Mant \& Wright (1954) and Wright (1958) a previous experience with horse antitoxic serum leads to a greatly accelerated elimination of passive immunity, and hence reliance placed on passive immunity should not be too great. Partly based on these observations, others (Hunter, 1959; Madigan, 1957) have questioned the very basis of the prophylactic use of A.T.S.

The report of the Army Pathology Advisory Committee (Barr \& Sachs, 1955) recorded masking of the action of tetanus toxoid by the simultaneous administration of A.T.S. Parish (1958) and Gardner (1960) advocate an interval of 6 weeks between the dose of A.T.S. and the first dose of toxoid. On the other hand, there are obvious advantages in starting the course of toxoid injections on the same day as A.T.S. in an accident case. Indeed, Eckmann (1959) advocates simultaneous use of serum and toxoid in the prophylaxis of tetanus, a technique used extensively in a number of hospitals throughout Australia.

The present study was undertaken to elucidate answers to some of these problems. In addition, because of the well-known complications following the use of horse A.T.S., investigations in animals and man were also done with homologous A.T.S.

\section{(1) Tetanus antitoxins}

\section{MATERIALS AND METHODS}

(a) Horse tetanus antitoxin (A.T.S.) used was that commercially prepared for human use at the Commonwealth Serum Laboratories, Melbourne (C.S.L.). It is a refined and concentrated solution of antitoxin globulins. The serum was diluted with normal saline for use so that the required number of units for each animal was contained in a given volume. While diluting the serum, account was taken of the excess unitage incorporated in the vials to provide for deterioration on storage.

* Present address. Central Research Institute, Kasauli, India. 
(b) Guinea-pig tetanus antitoxin was prepared by injecting adult guinea-pigs at 4-week intervals with two doses of purified tetanus toxoid (aluminium phosphate adsorbed). Animals were bled to death 2 weeks after the second dose and the serum separated. On assay for tetanus antitoxin content it was found to have $30 \mathrm{units} / \mathrm{ml}$. Unless otherwise indicated, the antitoxin unitage has been expressed here in terms of the 1950 International unit (which is equal to the American unit).

(c) Rabbit tetanus antitoxin was prepared by hyperimmunization of rabbits. When the animals had come to titre, $40 \mathrm{ml}$. of blood was collected from each rabbit 7-8 days after the last injection.

(d) Human tetanus antitoxin was concentrated human serum processed for this study at the C.S.L. Blood plasma for this purpose was obtained through the courtesy of Dr G. T. Archer of the Australian Red Cross Society, Sydney, from volunteers who had been actively immunized against tetanus. The final concentrated antitoxic serum had a titre of $40 \mathrm{units} / \mathrm{ml}$.

(2) Tetanus toxoids

(a) Fluid toxoid was formalinized fluid toxoid (tetanus vaccine B.P.) prepared at C.S.L. for human use. Batch no. 0182 was used in all experiments.

(b) Adsorbed toxoid was purified tetanus toxoid (aluminium phosphate adsorbed) prepared at C.S.L., batch no. 0154. This had $10 \mathrm{Lf} / \mathrm{ml}$. of tetanus toxoid and $10 \mathrm{mg} . / \mathrm{ml}$. of the mineral carrier.

\section{(3) Animals}

Rabbits, guinea-pigs and mice were obtained from the stock bred at the C.S.L. These animals were suitably housed and fed on prepared pellets and water ad lib. Rabbits were kept in individual cages.

\section{(4) Sensitized animals and sensitized humans}

In the case of rabbits, 6 weeks after a large dose of horse A.T.S. sensitivity was tested by intradermal injection of the serum. Rabbits showing an induration of 2-3 cm. with surrounding erythema within $4 \mathrm{hr}$. were classed as sensitized.

In the case of humans, however, persons giving a previous history of receiving either A.T.S. or other antitoxic sera prepared from horse serum have been classified as sensitive persons irrespective of whether a skin test was done or not.

\section{(5) Blood serum samples}

Rabbits were bled from the marginal ear vein and the blood was allowed to clot. The serum was collected aseptically and merthiolate was added to a final concentration of $1 / 10,000$ as a bacteriostat. The sera were stored at $4^{\circ} \mathrm{C}$. until required for use.

(6) Glassware

Glassware used for assay of tetanus antitoxic sera was cleansed as recommended in Standard Methods (Wadsworth, 1947). 


\section{(7) Standard test toxin}

Dry tetanus test toxin, lot no. SM 2074D, was obtained from C.S.L. for use as the Standard Test Toxin for assay of antitoxic content of sera, as well as for challenge purposes. This toxin had been in use at the C.S.L., as a test toxin, for the previous 12 months. Glenny \& Stevens (1938) have stressed the importance of using a toxin containing a relatively large number of M.L.D.'s per $\mathrm{L}^{+}$dose, especially when testing sera with low values of antitoxin. On test this toxin gave the following values:

$\begin{array}{ll}\text { M.L.D. for mice (14-18 g.) } & 0.000013 \mathrm{mg} . \\ \mathrm{L}^{+} / 100 \text { test dose for mice (14-18 g.) } & 0.0013 \mathrm{mg} . \\ \text { M.L.D. for guinea-pigs (350-400 g.) } & 0.000043 \mathrm{mg} .\end{array}$

Thus, one $\mathrm{L}^{+} / 100$ test dose of this test toxin contained 100 M.L.D. and one $\mathrm{L}^{+} / 1000$ test dose at least 10 M.L.D.

The dry toxin was stored in a sealed container over $\mathrm{P}_{2} \mathrm{O}_{5}$ at $4^{\circ} \mathrm{C}$. Every week a weighed quantity of this toxin was dissolved in $0.5 \%$ peptone saline. Merthiolate, $1 / 10,000$, was added as a preservative and the solution stored at $4^{\circ} \mathrm{C}$. For assay of antitoxin during the week this stock solution was further diluted, just prior to use, with normal saline.

For challenge of guinea-pigs and mice, the stock solution was diluted in $0.5 \%$ peptone saline. When normal saline was used as the diluent instead of peptonesaline the results were erratic.

\section{(8) Standard Tetanus Antitoxin}

The Standard Tetanus Antitoxin preparation, supplied by the M.R.C. (England) in a solution of $10 \mathrm{units} / \mathrm{ml}$., was used as standard control serum in all assays. The standard serum was stored at $4^{\circ} \mathrm{C}$.

\section{(9) Serum antitoxin titrations}

The antitoxin titrations were performed by means of the technique of Glenny \& Stevens (1938). Briefly, mixtures of tetanus toxin and properly diluted sera were incubated at $37^{\circ} \mathrm{C}$. for $1 \mathrm{hr}$. and then injected subcutaneously into mice weighing 14-18 g. Six mice were used for each serum dilution in the case of rabbit sera and three mice for each dilution in the case of human sera.

\section{(10) Level of passive immunity}

In the case of man and rabbit this was determined by taking samples of venous blood after a dose of tetanus antitoxin (heterologous or homologous). Tetanus antitoxin titre (units $/ \mathrm{ml}$. of serum) of these samples was then determined by the in vivo mouse test. For guinea-pigs and mice, passive immunity was tested in a more direct way. A challenge dose of tetanus toxin, 10-20 M.L.D., was given to each animal and if the animal survived this challenge it was considered immune. 


\section{(11) Observations of animals and recording}

Mice were observed daily for 7 days after injection of toxin-antitoxin mixtures, and on each day the number of mice dying of tetanus was noted for each dilution of the serum. On the seventh day, survivors were listed either as 'With tetanus' or 'No tetanus'. In borderline cases the animal was put on its back and if it could easily turn over it was listed as 'No tetanus'.

The following scoring system (after Ipsen, 1952) for mice was adopted to get the proportionate unitage of the sample under test in comparison with the Standard Antitoxin.

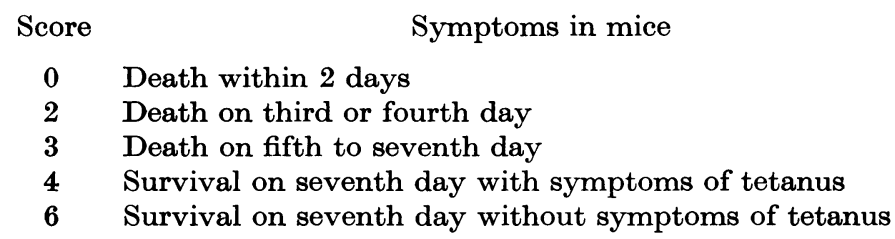

In general, rabbit sera were not titrated for values below $0.01 \mathrm{unit} / \mathrm{ml}$. To make an assay test to detect $0.01 \mathrm{unit} / \mathrm{ml}$. (using six mice per serum dilution) at $\mathrm{L}^{+} / 1000$ dose level of test-toxin requires about $1.5 \mathrm{ml}$. of serum. To carry out assay test at $\mathrm{L}^{+} / 100$ dose level of test-toxin would have necessitated use of 10 times this amount of serum, a quantity which is obviously not practicable or desirable to have from rabbits, especially when repeated bleedings have to be done for estimation of level of passive immunity.

Hence, most of the assays on rabbit sera have been done at $L^{+} / 1000$ dose level of test-toxin, except that when the sample was expected to have 1 unit or more per ml., assay was done at $\mathrm{L}^{+} / 100$ level. Thus, rabbit sera taken within 3 days of the administration of a large dose of antitoxin (in experiments for rate of elimination of heterologous antitoxin) and sera collected after a second dose of tetanus toxoid were tested at $\mathrm{L}^{+} / 100$ dose level of test-toxin.

In the study of the duration of passive immunity in man with homologous and heterologous A.T.S. all human sera were tested at $\mathrm{L}^{+} / 1000$ dose level of test-toxin.

The variation in the value of the Standard Antitoxin obtained in these tests was subjected to statistical analysis.

Tests at $\mathrm{L}^{+} / 100$ level ( 6 mice/dilution):

$$
\begin{array}{ll}
\text { No. of tests } & =14 \\
\text { Mean } & =1 \cdot 044 \\
\text { Standard deviation } & =0 \cdot 0434 \\
95 \% \text { fiducial limits } & =91 \cdot 8-108 \cdot 2 \%
\end{array}
$$

Tests at $\mathrm{L}^{+} / 1000$ level (6 mice/dilution):

$$
\begin{array}{ll}
\text { No. of tests } & =31 \\
\text { Mean } & =1 \cdot 152 \\
\text { Standard deviation } & =0 \cdot 0321 \\
95 \% \text { fiducial limits } & =93 \cdot 7-106 \cdot 3 \%
\end{array}
$$


Tests at $\mathrm{L}^{+} / 1000$ level (3 mice/dilution):

$$
\begin{array}{ll}
\text { No. of tests } & =11 \\
\text { Mean } & =1 \cdot 121 \\
\text { Standard deviation } & =0 \cdot 0951 \\
95 \% \text { fiducial limits } & =83 \cdot 4-116 \cdot 6 \%
\end{array}
$$

Thus, the tests with 6 mice/dilution vary to about the extent predicted in the B.P. 1958. The tests with 3 mice/dilution vary to a greater extent than predicted in the B.P.

\section{EXPERIMENTAL RESULTS \\ Passive immunization}

Investigations made on passive immunization against tetanus can be broadly put under the following four headings:

A. Study of duration of passive immunity in animals conferred by heterologous (horse) tetanus antitoxin.

B. Passive immunization in animals with homologous tetanus antitoxin.

C. Study of duration of passive immunity in man conferred by heterologous (horse) tetanus antitoxin.

D. Passive immunization in man with homologous tetanus antitoxin.

\section{A. Duration of passive immunity in animals conferred by heterologous (horse) tetanus antitoxin}

This was studied in rabbits, guinea-pigs and mice. In rabbits the level of serum antitoxin after a dose of tetanus antitoxin was followed in normal animals and in rabbits previously sensitized to horse antitoxin. The results are shown in Table 1.

Table 1. Antitoxin levels in rabbits after intravenous injection of 500 units $/ \mathrm{kg}$. body weight of horse A.T.S.

$\begin{array}{lcc} & \begin{array}{c}\text { Normal rabbits } \\ (4 \text { animals })\end{array} & \begin{array}{c}\text { Sensitized rabbits } \\ \text { (4 animals) } \\ \text { average }\end{array} \\ \text { Time of bleed } & <0.01 & <0.01 \\ \text { Before injection } & 12.22(100 \%) & 14.31(100 \%) \\ \frac{1}{2} \text { hr. after injection } & 4 \cdot 44(36.3 \%) & 4.79(33.5 \%) \\ 24 \text { hr. after injection } & 2 \cdot 47(20.2 \%) & 1.51(10.5 \%) \\ 3 \text { days after injection } & 0.494(4.0 \%) & 0.076(0.5 \%) \\ 7 \text { days after injection } & 0.072(0.6 \%) & 0.005(0.03 \%) \\ \text { 10 days after injection } & <0.01(<0.08 \%) & <0.01-\end{array}$

It will be seen that the passive immunity $(0.02$ unit $/ \mathrm{ml}$. or more) induced by a large intravenous dose ( $500 \mathrm{units} / \mathrm{kg}$. body weight) of heterologous serum is of equally short duration in normal and sensitized animals. In normal animals, for instance, the serum A.T.S. level fell to less than $1 \%$ of the initial level after 10 days and in sensitized animals a similar loss took place in 7 days. However, when 
A.T.S. was given subcutaneously the rate of elimination, as measured by comparison of serum levels, was more rapid in the sensitized animals (Table 2).

The duration of passive immunity in guinea-pigs following heterologous (horse) antitoxic serum is limited no matter how large a dose of antitoxin is administered. In Table 3 it will be seen that the degree of protection is about the same for doses of antitoxin varying from 12.5 to $250 \mathrm{units} / \mathrm{kg}$. of body weight. When the dose of antitoxin was increased to 1250 units the animals were immune on the fourteenth day but not on the twenty-first day.

Similar results were also obtained in mice. Increasing tetanus antitoxin from 10 units to 100 units/mouse failed to protect the animals when challenged with 20 M.L.D. of toxin at the fourteenth day.

Table 2. Antitoxin levels in rabbits after subcutaneous injection of 500 units/kg. body weight of horse A.T.S.

\begin{tabular}{|c|c|c|}
\hline \multirow[b]{2}{*}{ Time of bleed } & \multicolumn{2}{|c|}{ Serum antitoxin level (units/ml.) } \\
\hline & $\begin{array}{l}\text { Normal rabbits } \\
\text { (2 animals), } \\
\text { average }\end{array}$ & $\begin{array}{l}\text { Sensitized rabbits, } \\
\text { (2 animals), } \\
\text { average }\end{array}$ \\
\hline Before injection & $<0.01$ & $<0.01$ \\
\hline $24 \mathrm{hr}$. after injection & $2 \cdot 34(100 \%)$ & $2.49(100 \%)$ \\
\hline 3 days after injection & $1.46(62 \cdot 4 \%)$ & $1.81(72 \cdot 2 \%)$ \\
\hline 7 days after injection & $0.44(18.8 \%)$ & $0.02(0.8 \%)$ \\
\hline 10 days after injection & $0.086(3.7 \%)$ & $<0.01(0.4 \%)$ \\
\hline 14 days after injection & $<0.01$ & - \\
\hline
\end{tabular}

Table 3. Duration of passive immunity in guinea-pigs after subcutaneous injection of horse A.T.S.

Immunization

A.T.S. per kg. (units)

Result of challenge with tetanus toxin after

$\begin{array}{ccccc}\text { (units) } & 1 \text { day } & 7 \text { days } & 14 \text { days } & 21 \text { days } \\ 1.25 & 4 / 4^{*} & 0 / 4 & - & - \\ 12.5 & - & 4 / 4 & 0 / 4 & - \\ 25 \cdot 0 & - & 4 / 4 & 0 / 4 & - \\ 250 \cdot 0 & - & 4 / 4 & 1 / 6 & 0 / 6 \\ 1250 \cdot 0 & - & 6 / 6 & 6 / 6 & 0 / 6\end{array}$

* No. survivors/No. challenged. Challenge dose of toxin $=20$ M.L.D. subcutaneously.

B. Duration of passive immunity in animals conferred by homologous A.T.S.

Normal adult rabbits were injected with a single dose of rabbit tetanus antitoxic serum. Two rabbits received 50 units $/ \mathrm{kg}$. intravenously; another two $12.5 \mathrm{units} / \mathrm{kg}$. intravenously, while a third group of two rabbits was given 50 units $/ \mathrm{kg}$. subcutaneously. The A.T.S. serum levels in these animals over a period of 4-6 weeks are shown in Tables 4 and 5.

It is evident that the serum A.T.S. level remains much higher following homologous A.T.S. than that obtained with a tenfold greater dose of antiserum (cf. Tables 2 and 5). Further, the rate of disappearance of homologous antitoxin 
is uninfluenced by the route of administration. The average titre of the circulating antitoxin from the third day onwards was no less in animals receiving 50 units/kg. of homologous antitoxin subcutaneously (Table 5) than in those receiving the same dose intravenously (Table 4). Fig. 1 shows clearly the excretion curves of homologous and heterologous A.T.S. in rabbits.

Table 4. Antitoxin levels in rabbits after intravenous injection of homologous A.T.S.

Serum antitoxin level (units/ml.)

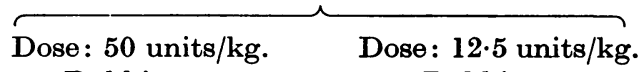

Rabbit no.

\begin{tabular}{|c|c|c|c|c|c|}
\hline \multirow[b]{2}{*}{ Time of bleed } & & & \multirow{2}{*}{$\underset{\text { level }}{\text { Mean }}$} \\
\hline & R 879 & R 844 & $\mathrm{R} 847$ & R 877 & \\
\hline Before injection & $<0.01$ & $<0.01$ & $<0.01$ & $<0.01$ & - \\
\hline$\frac{1}{2}$ hr. after injection & $\begin{array}{l}0.92 \\
(100 \%)\end{array}$ & $\begin{array}{c}0.85 \\
(100 \%)\end{array}$ & $\begin{array}{r}0.292 \\
(100 \%)\end{array}$ & $\begin{array}{r}0.281 \\
(100 \%)\end{array}$ & 100 \\
\hline 1 day after injection & $\begin{array}{c}0.37 \\
(40.2 \%)\end{array}$ & $\begin{array}{c}0.36 \\
(42.3 \%)\end{array}$ & $\begin{array}{c}0.099 \\
(33.9 \%)\end{array}$ & $\begin{array}{c}0.089 \\
(31.6 \%)\end{array}$ & $37 \cdot 0$ \\
\hline 3 days after injection & $\begin{array}{c}0.304 \\
(33.0 \%)\end{array}$ & $\begin{array}{c}0.257 \\
(30.2 \%)\end{array}$ & $\begin{array}{c}0.082 \\
(28.0 \%)\end{array}$ & $\begin{array}{c}0.053 \\
(18.8 \%)\end{array}$ & $27 \cdot 2$ \\
\hline 7 days after injection & $\begin{array}{c}0.231 \\
(25.1 \%)\end{array}$ & $\begin{array}{c}0.132 \\
(15.5 \%)\end{array}$ & $\begin{array}{c}0.046 \\
(15.7 \%)\end{array}$ & $\begin{array}{c}0.028 \\
(10.2 \%)\end{array}$ & $16 \cdot 6$ \\
\hline 14 days after injection & $\begin{array}{c}0.088 \\
(9.6 \%)\end{array}$ & $\begin{array}{c}0.053 \\
(6.2 \%)\end{array}$ & $\begin{array}{c}0.027 \\
(9 \cdot 3 \%)\end{array}$ & $\begin{array}{l}<0.01 \\
(<3.5 \%)\end{array}$ & $7 \cdot 0$ \\
\hline 21 days after injection & $\begin{array}{c}0.029 \\
(3.1 \%)\end{array}$ & $\begin{array}{c}0.022 \\
(2.6 \%)\end{array}$ & $\begin{array}{c}<0.01 \\
(<3.4 \%)\end{array}$ & $\begin{array}{c}<0.01 \\
(<3.5 \%)\end{array}$ & $<2 \cdot 0$ \\
\hline 28 days after injection & 0.012 & $<0.01$ & $<0.01$ & $<0.01$ & - \\
\hline
\end{tabular}

Table 5. Antitoxin levels in rabbits after subcutaneous injection of 50 units $/ \mathrm{kg}$. body weight of homologous A.T.S.

\begin{tabular}{|c|c|c|c|}
\hline \multirow[b]{2}{*}{ Time of bleed } & \multicolumn{2}{|c|}{$\begin{array}{c}\text { Serum antitoxin level } \\
\text { (units/ml.) } \\
\text { Rabbit no. }\end{array}$} & \multirow{2}{*}{$\begin{array}{c}\text { Averag } \\
\text { (units) }\end{array}$} \\
\hline & R 850 & R 876 & \\
\hline Before injection & $<0.01$ & $<0.01$ & $<0.01$ \\
\hline 1 day after injection & $0 \cdot 185$ & $0 \cdot 175$ & $0 \cdot 180$ \\
\hline 3 days after injection & $0 \cdot 381$ & 0.328 & 0.354 \\
\hline 7 days after injection & $0 \cdot 377$ & 0.224 & $0 \cdot 300$ \\
\hline 14 days after injection & $0 \cdot 160$ & $0 \cdot 067$ & $0 \cdot 113$ \\
\hline 21 days after injection & 0.092 & 0.032 & 0.062 \\
\hline 28 days after injection & 0.022 & $<0.01$ & $<0.01$ \\
\hline 35 days after injection & 0.014 & $<0.01$ & $<0.01$ \\
\hline 42 days after injection & $<0.01$ & $<0.01$ & $<0.01$ \\
\hline
\end{tabular}

In Table 6 the results of protection tests in guinea-pigs are summarized. The animals were passively protected by a subcutaneous injection of either heterologous or homologous A.T.S. and, at varying intervals of time, challenged with tetanus toxin. The duration of passive immunity with homologous A.T.S., even with a dose of 2.5 units $/ \mathrm{kg}$. (1 unit for an adult guinea-pig weighing $400 \mathrm{~g}$.), was 
at least 21 days. On the other hand, heterologous (horse) A.T.S. in a dose 100 times greater than this $(250 \mathrm{units} / \mathrm{kg}$.) failed to protect the animals when challenged 14 days later.

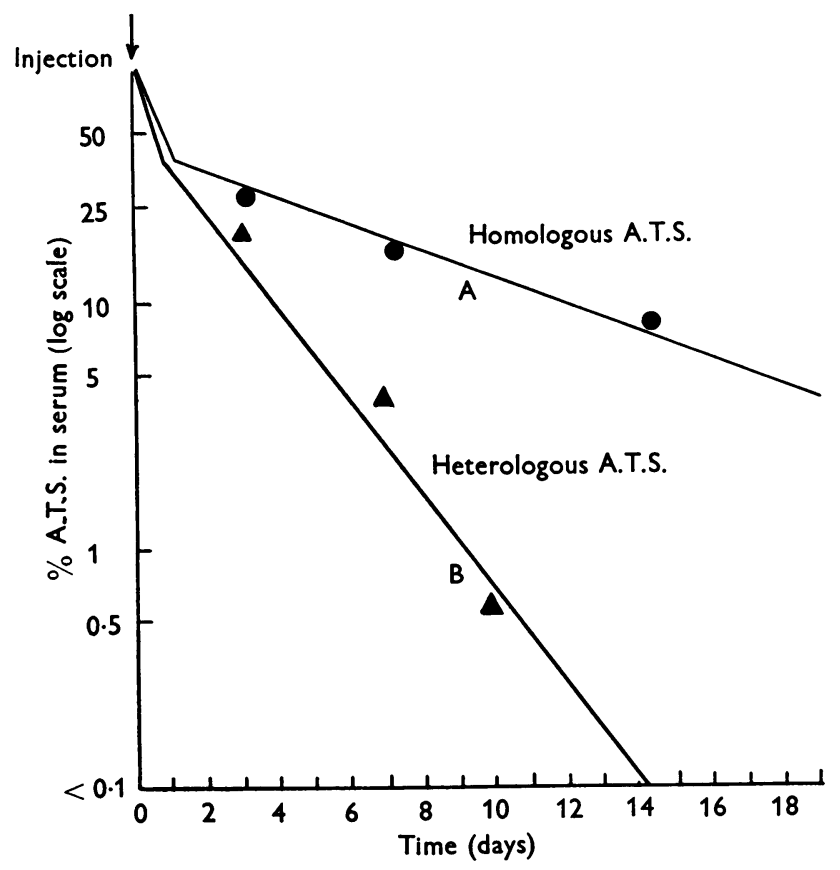

Fig. 1. Rate of disappearance of tetanus antitoxin following passive immunization of rabbits. Dose: homologous A.T.S. 50 units $/ \mathrm{kg}$. intravenously; heterologous A.T.S. 500 units $/ \mathrm{kg}$. intravenously.

Table 6. Duration of passive immunity in guinea-pigs after homologous and heterologous A.T.S.

\begin{tabular}{cccc} 
& \multicolumn{3}{c}{$\begin{array}{c}\text { Result of challenge with } \\
\text { tetanus toxin after }\end{array}$} \\
Immunization & $\overbrace{7 \text { days }}$ & 14 days & 21 days \\
Untreated & $0 / 6^{*}$ & $0 / 6$ & $0 / 6$ \\
Homologous A.T.S. & $6 / 6$ & $6 / 6$ & $6 / 6$ \\
Dose : $2 \cdot 5$ units $/ \mathrm{kg}$. & & & $0 / 6$ \\
Heterologous A.T.S. & $6 / 6$ & $0 / 6$ \\
Dose: 250 units $/ \mathrm{kg}$. & & &
\end{tabular}

Dose: 250 units $/ \mathrm{kg}$.

* No. survivors/No. challenged.

Challenge dose of toxin $=20$ M.L.D. subcutaneously.

C. Duration of passive immunity in man conferred by heterologous (horse) A.T.S.

In our previous experiments on rabbits it was observed that A.T.S., when given subcutaneously, was eliminated more rapidly in the sensitized animals (Table 2). It has been suggested that the same phenomenon occurs in man and that this could have serious complications (Wright, 1958). Thus, it is of interest to know if a person who has had either A.T.S. or another type of therapeutic horse serum 
would eliminate a dose of A.T.S. so rapidly that the serum level would be below $0.02 \mathrm{unit} / \mathrm{ml}$. during the incubation period of 7-10 days.

To elucidate this point, accident cases receiving a prophylactic injection of 1500 units of A.T.S. subcutaneously were bled on two occasions. The first sample of blood was taken 2 days after injection and a second sample was collected at 5,7 or 10 days.

The cases were treated at different hospitals in Melbourne and at Ballarat during October to December 1959. Each hospital followed its own routine and no attempt was made to prescribe a uniform immunization treatment. Thus, some hospitals gave only antitoxin and others used toxoid at the same time but injected at a different site. While most of the cases received 1500 units of antitoxin, some were given 10,000 units. Although the second sample of blood was collected on a day convenient to the hospital concerned, most of the samples were taken on the seventh day. A total of 106 samples of blood from fifty-three patients was assayed for tetanus antitoxin titre.

The antitoxin levels in sera following an injection of 1500 units of antitoxin (with or without a simultaneous dose of toxoid) in normal subjects have been tabulated in Table 7. Those patients who gave a history of previous injections of either A.T.S. or other antitoxic sera prepared from horse serum have been recorded separately (Table 8) and have been classified as sensitive persons. The levels of antitoxin following administration of 10,000 units (7 cases) are shown in Table 9.

From Tables 7 and 8 it is apparent that although the elimination of tetanus antitoxin is variable in different individuals, approximately $80-85 \%$ have a protective level of antitoxin that is greater than $0.02 \mathrm{unit} / \mathrm{ml}$., for at least 7 days after injection of 1500 units subcutaneously. It is also interesting to note that the level of A.T.S. in normal ( 29 cases) and sensitized (17 cases) groups shows similar general distribution. There appears to be no marked trend among the sensitized individuals to excrete A.T.S. more rapidly than normal subjects following subcutaneous injection.

Among the seven patients receiving 10,000 units of A.T.S. (Table 9) two showed rapid elimination. One (case no. 2), who had no previous contact with horse serum, had $0.875 \mathrm{unit} / \mathrm{ml}$. on the second day and only $0.075 \mathrm{unit} / \mathrm{ml}$. on the seventh day. The other (case no. 6), with a history of previous injection of A.T.S., had $0.514 \mathrm{unit} / \mathrm{ml}$. on the second day and $0.097 \mathrm{unit} / \mathrm{ml}$. on the eighth day. However, the average serum levels in the remainder, normal and sensitized, do not differ from one another by more than $10 \%$, a difference which cannot be regarded as significant.

\section{Duration of passive immunity in man conferred by homologous A.T.S.}

Eight young male volunteers, approximately $70 \mathrm{~kg}$. weight, were injected with 200 units of human A.T.S.-four intramuscularly and four intravenously. Two in each group were also given adsorbed tetanus toxoid subcutaneously at the same time as the A.T.S. but in the opposite limb. Ten to $15 \mathrm{ml}$. blood samples were collected from each before treatment and then at 2, 7, 14 and 21 days after immunization. The sera were assayed and the results are shown in Table 10. 
Table 7. Antitoxin levels in normal persons after subcutaneous injection of heterologous (horse) A.T.S., alone or with toxoid

(Dose: 1500 units A.T.S.)

Time of bleed (after injection)

No. of sera with A.T.S. levels. Range units per ml.

Total $0.2-0.5 \quad 0.1-0.2 \quad 0.05-0.1 \quad 0.02-0.05 \quad<0.02$ no. of

2 days
5 days
7 days
10 days

$\begin{array}{cc}7 & 18(62 \%) \\ - & 7 \\ - & 9(45 \%)\end{array}$

- $8(40 \%)$

-
samples

Total 29 7 20 2 58

Table 8. Antitoxin levels in sensitized persons after subcutaneous injection of heterologous (horse) A.T.S., alone or with toxoid

(Dose: 1500 units A.T.S.)

Time of bleed (after injection)

No. of sera with A.T.S. levels. Range units per ml.

Total

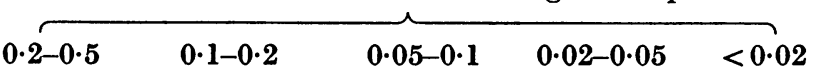
no. of

2 days
5 days
7 days
10 days

$\begin{array}{ll}2 & 11(65 \%) \\ 1 & 3(50 \%) \\ - & 5(50\end{array}$

$\begin{array}{lll}4 & - & - \\ -3(30 \%) & - & - \\ 2 & - & 1\end{array}$
samples

Table 9. Antitoxin levels in persons after subcutaneous injection of heterologous (horse) A.T.S.

(Dose: 10,000 units A.T.S.)

\begin{tabular}{|c|c|c|c|c|}
\hline \multirow{2}{*}{$\begin{array}{c}\text { Case no. } \\
1\end{array}$} & \multirow{2}{*}{$\begin{array}{c}\text { History of } \\
\text { previous } \\
\text { injection of } \\
\text { horse serum } \\
\text { Nil }\end{array}$} & \multirow{2}{*}{$\begin{array}{c}\text { Toxoid } \\
\text { given } \\
\text { No }\end{array}$} & \multicolumn{2}{|c|}{ Serum antitoxin level (units/ml.) } \\
\hline & & & 0.588 (2 days) & 0.409 (7 days) \\
\hline 2 & Nil & No & 0.875 (2 days) & 0.075 (7 days) \\
\hline 3 & Nil & No & 0.539 (2 days) & $0 \cdot 368$ (10 days $)$ \\
\hline 4 & Nil & Yes & 0.847 (2 days) & 0.218 (12 days) \\
\hline 5 & Yes & Yes & 0.875 (2 days) & 0.463 (5 days) \\
\hline 6 & Yes & Yes & 0.514 (2 days) & 0.097 (8 days) \\
\hline 7 & Yes & No & 0.539 (2 days) & 0.241 ( 10 days) \\
\hline
\end{tabular}

A number of interesting points are brought out in this experiment. Briefly, it is evident that homologous antitoxin is not rapidly eliminated; in fact the average titre at 21 days after intramuscular injection was unchanged, namely $0.02 \mathrm{unit} / \mathrm{ml}$. This contrasts markedly with the results obtained using high doses of heterologous antitoxin (Table 7). Secondly, the simultaneous administration of toxoid did not lower the antitoxin level and conversely the antitoxin did not interfere with the secondary immune response in subject $\mathrm{H}$ who must have had previous active 
immunization. Finally, the route of administration did not affect serum levels after the seventh day.

\section{Combined active and passive immunization}

Active immunization with fluid or adsorbed tetanus toxoids induces, after the first dose, a primary response (circulating antitoxin) and sensitization of the antibody-forming tissues. When a second dose of toxoid is given a few weeks later, a secondary type of response is detectable which is characterized by a rapid rise in the serum antitoxin level within 7 days. If, however, tetanus antitoxin is administered simultaneously with the first dose of toxoid, interference with the primary response to the toxoid may result. In addition, the toxoid may also fail to sensitize the tissues of the animal, so that when the second dose of toxoid is given the secondary type of response is absent.

Table 10. Antitoxin levels in volunteers after injection of 200 units of homologous (human) A.T.S.

\begin{tabular}{|c|c|c|c|c|c|c|}
\hline \multirow[b]{2}{*}{ Subject } & \multirow[b]{2}{*}{ Immunization } & \multirow[b]{2}{*}{$\begin{array}{l}\text { Before } \\
\text { injection }\end{array}$} & \multicolumn{4}{|c|}{$\begin{array}{c}\text { Serum antitoxin level (units } / \mathrm{ml} \text {.) } \\
\text { after injection }\end{array}$} \\
\hline & & & 2 days & 7 days & 14 days & 21 days \\
\hline A & A.T.S.-I.M.* & & 0.020 & 0.023 & 0.020 & 0.016 \\
\hline & & & 0.024 & 0.030 & 0.023 & 0.022 \\
\hline $\begin{array}{l}\text { C } \\
\text { D }\end{array}$ & $\begin{array}{l}\text { A.T.S.-I.M. and toxoid } \\
\text { A.T.S.-I.M. and toxoid }\end{array}$ & $\begin{array}{l}<0.002 \\
<0.002\end{array}$ & $\begin{array}{l}0.021 \\
0.011\end{array}$ & $\begin{array}{l}0.025 \\
0.023\end{array}$ & $\begin{array}{l}0.023 \\
0.018\end{array}$ & $\begin{array}{l}0.021 \\
0.013\end{array}$ \\
\hline $\begin{array}{l}\mathbf{E} \\
\mathbf{F}\end{array}$ & $\begin{array}{l}\text { A.T.S.-r.v. } \dagger \\
\text { A.T.S.-r.v. }\end{array}$ & $\begin{array}{l}<0.002 \\
<0.002\end{array}$ & $\begin{array}{l}0.047 \\
0.040\end{array}$ & $\begin{array}{l}0.025 \\
0.026\end{array}$ & $\begin{array}{l}0.024 \\
0.023\end{array}$ & $\begin{array}{l}0.020 \\
0.021\end{array}$ \\
\hline $\begin{array}{l}\mathrm{G} \\
\mathrm{H}\end{array}$ & $\begin{array}{l}\text { A.T.S.-I.v. and toxoid } \\
\text { A.T.S.-I.v. and toxoid }\end{array}$ & $\begin{array}{l}>0.005 \\
>0.005\end{array}$ & $\begin{aligned} & 0.036 \\
> & 0.2\end{aligned}$ & $\begin{array}{r}0 \cdot 035 \\
0 \cdot 2-1 \cdot 0\end{array}$ & $\begin{array}{l}0.026 \\
>1.0\end{array}$ & $\begin{array}{c}0.021 \\
\text { not done }\end{array}$ \\
\hline
\end{tabular}

With a view to examining the influence of passive antitoxic immunity on these two functions of tetanus toxoid it was decided to give rabbits two doses of toxoid, the first accompanied by antitoxin and the second given alone 6 weeks later. This period was planned to allow for the excretion of detectable passive antitoxin and the appearance, if any, of actively produced antitoxin. A bleed, taken 7 days after the second dose of toxoid, would also show whether the antitoxin had nullified the animal's ability to respond in an immunologically expected manner to the second dose.

Four groups of two rabbits each were treated as follows:

Group I. Fluid tetanus toxoid subcutaneously- $0.5 \mathrm{ml} . / \mathrm{kg}$. body weight.

Group II. Fluid tetanus toxoid as in group I and in the opposite flank heterologous tetanus antitoxin (horse A.T.S.) subcutaneously -500 units $/ \mathrm{kg}$. body weight.

Groups III and IV corresponded to groups I and II respectively, except that adsorbed toxoid was used in place of fluid toxoid.

Three to $5 \mathrm{ml}$. samples of blood were taken before the start of the experiment 
and then at 7-day intervals for 6 weeks. At the end of 6 weeks all rabbits received a second injection of the respective toxoid in a dose of $0.5 \mathrm{ml} / \mathrm{kg}$. body weight. Seven days after this booster dose blood samples were again taken from the rabbits. The titre of tetanus antitoxin (units/ml.) in all sera was determined by in vivo assay in mice against M.R.C. Standard Antitoxin.

The results of this experiment can be most clearly recorded by graphs, as depicted in Figs. 2 and 3 below. Fig. 2 shows that the antitoxin response to fluid toxoid alone follows the expected pattern, namely a detectable titre commencing between the second and third weeks and marked secondary response to the second injection given 6 weeks later. However, when serum was given at the same time as the first dose the animals showed no primary response, that is, no detectable circulating
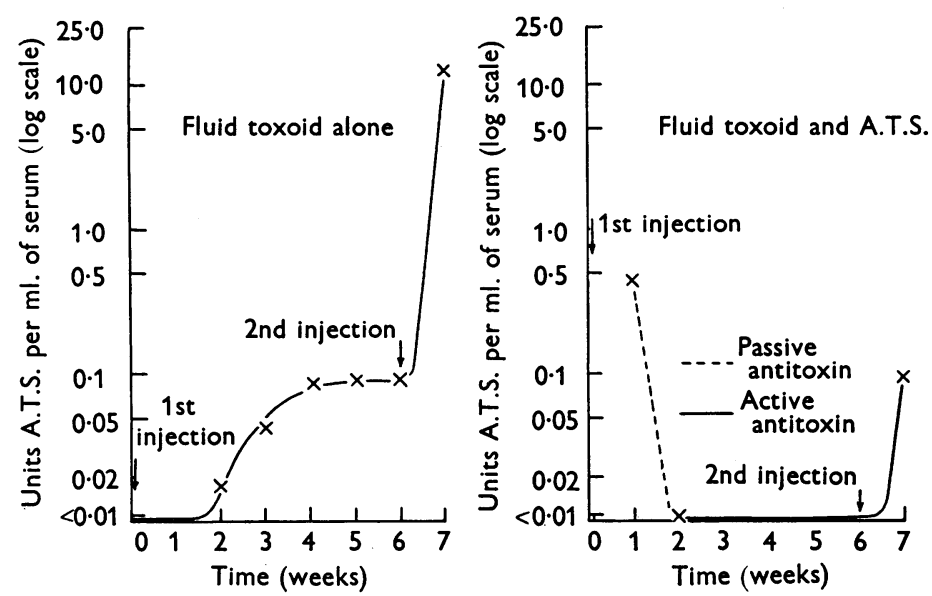

Fig. 2. Interference of primary immune response by simultaneous injection of A.T.S. Dose: fluid toxoid $0.5 \mathrm{ml} . / \mathrm{kg}$. body weight. Heterologous A.T.S. 500 units $/ \mathrm{kg}$. body weight.

antitoxin over the 6-week period. The secondary response was also of a low titre, $0.9 \mathrm{unit} / \mathrm{ml}$., as compared with $12.72 \mathrm{units} / \mathrm{ml}$. in group I, indicating that the heterologous A.T.S. had grossly interfered with the immunogenic action of the fluid toxoid.

Adsorbed tetanus toxoid alone (group III) provoked a good primary response in the rabbits in 2-3 weeks followed by a sharp secondary response when the second dose of toxoid was given 6 weeks later. The final titre of antitoxin was significantly higher than that produced by fluid toxoid (cf. Figs. 2 and 3 ). This would seem to indicate that adsorbed tetanus toxoid is a better antigen than the fluid toxoid. When heterologous tetanus antitoxin was also given at the same time as the first dose of adsorbed toxoid (group IV), the passive antitoxin was eliminated within the first 2 weeks and then there was a period of 2 weeks during which there was no detectable circulating antitoxin (passive or active) present; after this actively produced antitoxin began to appear. However, the final titre of antitoxin reached as the primary response to the first dose of toxoid was lower than in 
group III, where toxoid only was injected. The secondary response was similar in both groups III and IV.

Interference with the primary immune response by simultaneous administration of A.T.S. was also demonstrated in guinea-pigs by challenging animals with 20 M.L.D. tetanus toxin at varying intervals after active and combined active and passive immunization. These animals received only one dose of toxoid, and the results are listed in Table 11 below.
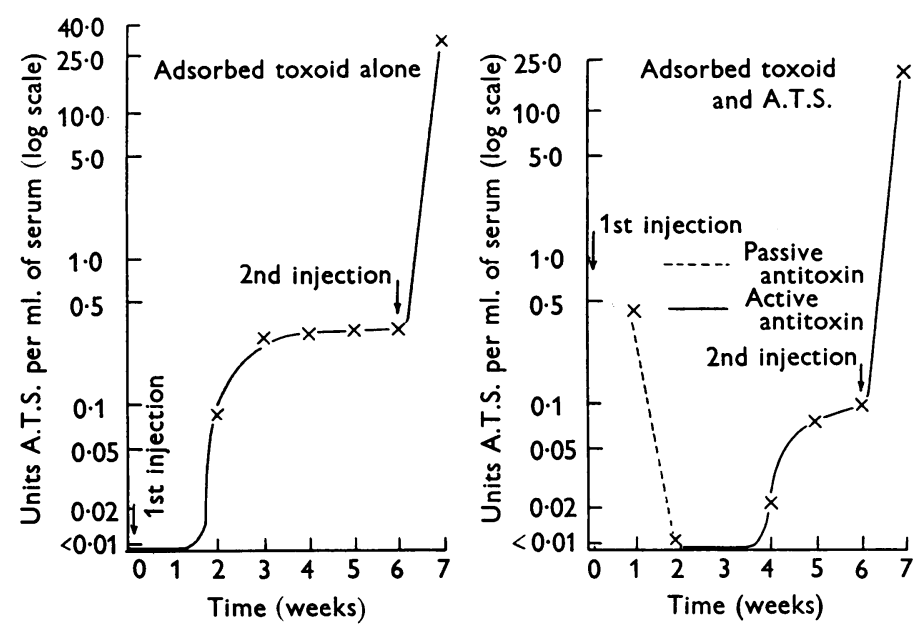

Fig. 3. Interference of primary immune response by simultaneous injection of A.T.S. Dose: adsorbed toxoid $0.5 \mathrm{ml} . / \mathrm{kg}$. body weight. Heterologous A.T.S. 500 units $/ \mathrm{kg}$. body weight.

Table 11. Development of immunity in guinea-pigs following combined active and passive immunization

\begin{tabular}{|c|c|c|c|c|}
\hline \multirow[b]{2}{*}{ Group } & \multirow[b]{2}{*}{ Immunization } & \multicolumn{3}{|c|}{$\begin{array}{l}\text { Result of challenge with } \\
\text { tetanus toxin after }\end{array}$} \\
\hline & & 7 days & 14 days & 21 days \\
\hline I & Untreated controls & $0 / 6^{*}$ & $0 / 6$ & $0 / 6$ \\
\hline II & $\begin{array}{l}\text { Adsorbed toxoid. } 0.25 \mathrm{ml} . / \mathrm{kg} \text {. body } \\
\text { weight s.c. }\end{array}$ & $0 / 9$ & $9 / 9$ & $9 / 9$ \\
\hline III & A.T.S. 250 units $/ \mathrm{kg}$. body weight s.c. & $12 / 12$ & $3 / 12$ & $0 / 12$ \\
\hline IV & $\begin{array}{l}\text { A.T.S. + adsorbed toxoid same day. } \\
\text { (Doses as above) }\end{array}$ & $6 / 6$ & $0 / 6$ & $0 / 6$ \\
\hline V & $\begin{array}{l}\text { A.T.S. + adsorbed toxoid } 7 \text { days later. } \\
\text { (Doses as above) }\end{array}$ & $6 / 6$ & $2 / 6$ & $6 / 6$ \\
\hline
\end{tabular}

* No. survivors/No. challenged. Challenge dose of toxin $=20$ M.L.D. subcutaneously.

It will be seen that all the guinea-pigs injected with adsorbed toxoid (group II) survived the challenge given on the fourteenth day onwards, and that none of the animals receiving antitoxin at the same time (group IV) survived. However, if the first dose of toxoid was given 7 days after the antitoxin (group V) there was no apparent interference with the immune response, since all animals survived the 
challenge with toxin 14 days later, that is, on the twenty-first day after first receiving A.T.S.

The effect of postponing the first dose of adsorbed toxoid for 7 days after the dose of A.T.S. was then measured in rabbits. The serum A.T.S. levels are shown in Fig. 4. It will be seen that rabbits which received the first dose of toxoid 7 days after the injection of A.T.S. (curve A) developed circulating antitoxin (active)

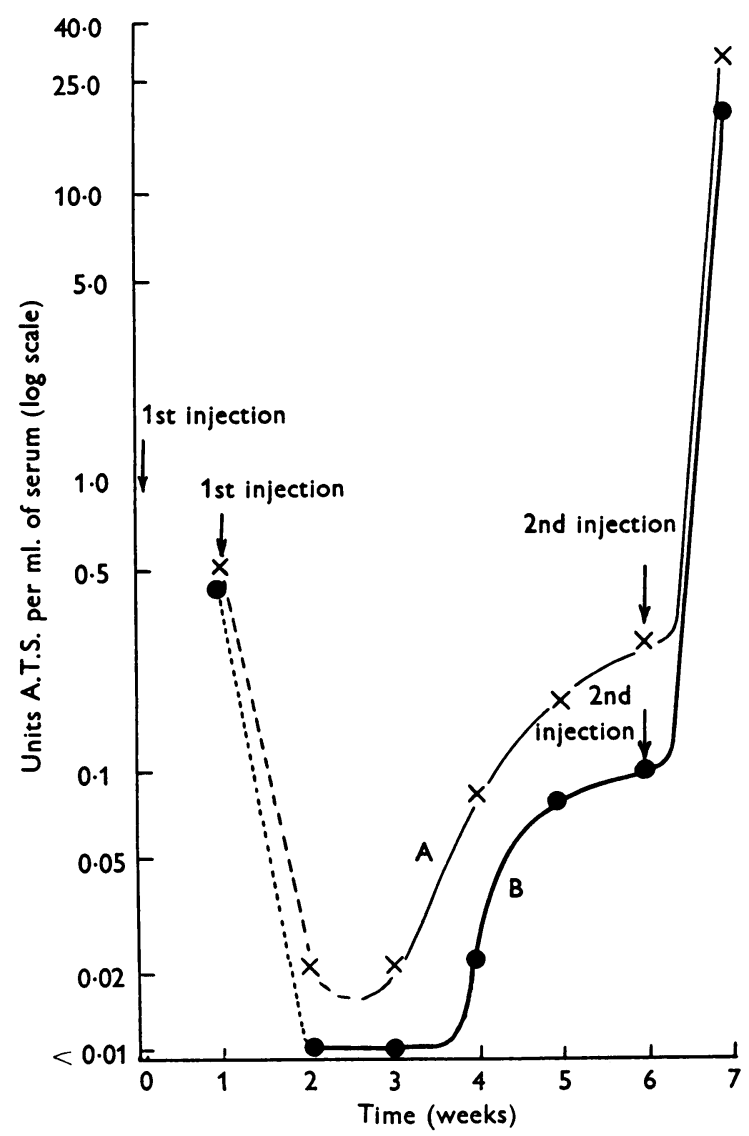

Fig. 4. Primary immune response following toxoid given 7 days after A.T.S. Dose: adsorbed toxoid $0.5 \mathrm{ml} . / \mathrm{kg}$. body weight. Heterologous A.T.S. 500 units $/ \mathrm{kg}$. body weight. $\mathbf{A}=$ A.T.S. followed by toxoid 7 days later; $B=A . T . S$. and toxoid same day. ----, Passive antitoxin $A ; \ldots .$. , passive antitoxin $B$; - active antitoxin $\mathrm{A} ;-$, active antitoxin $\mathrm{B}$.

before the complete elimination of passive antitoxin. The level of the primary response, as well as that of the secondary response, was good (cf. Fig. 3 for response to toxoid alone). Rabbits receiving the first dose of toxoid on the same day as the dose of A.T.S. (curve B) gave an antitoxin response intermediate between the control animals receiving toxoid only and the animals receiving toxoid 7 days after A.T.S.

The results both in guinea-pigs and in rabbits seemed to indicate that the level of passive antitoxin largely determined the extent of interference of the primary immune response. To test this experimentally, groups of mice were given varying 
amounts of A.T.S. with and without simultaneous injection of a standard dose of toxoid. The results, listed in Table 12 below, show that those which received toxoid together with 50 units of heterologous A.T.S. (horse) suffered $100 \%$ mortality when challenged 14 and 21 days later with 20 M.L.D. of tetanus toxin (group III). On the other hand, in those receiving only 5 units of A.T.S. and the same amount of toxoid (group II) only a $36 \%$ mortality rate at the twenty-first day was observed. This low mortality rate was not due to residual passive antitoxin

\section{Table 12. Effect of dosage of antitoxin in combined active and passive immunization of mice}

\begin{tabular}{ccccc} 
Group & $\begin{array}{c}\text { Adsorbed toxoid } \\
\text { dose per mouse } \\
\text { ml. }\end{array}$ & $\begin{array}{c}\text { Horse A.T.S. } \\
\text { donits }\end{array}$ & \multicolumn{1}{c}{$\begin{array}{c}\text { Result of challenge with } \\
\text { tetanus toxin after }\end{array}$} \\
\cline { 5 - 6 } I & 0.05 & Nil & 12 days & 21 days \\
II & 0.05 & 5 & $0 / 15^{*}$ & $15 / 17$ \\
III & 0.05 & 50 & $0 / 17$ & $14 / 22$ \\
IV & Nil & 5 & $0 / 12$ & $0 / 20$ \\
V & Nil & 50 & $0 / 12$ & $0 / 12$ \\
VI & Nil & Nil & $0 / 17$ & $0 / 12$ \\
Vil & & &
\end{tabular}

* No. survivors/No. challenged.

Challenge dose of toxin $=20$ M.L.D. subcutaneously. Weight of mice $=18-21 \mathrm{~g}$.
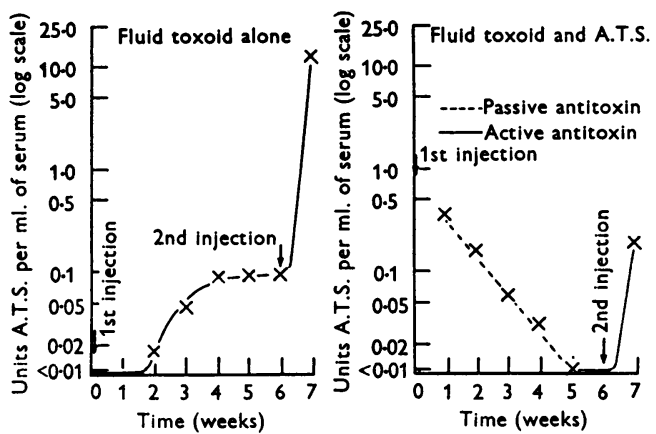

Fig. 5. Interference of primary immune response by simultaneous injection of A.T.S. Dose: fluid toxoid $0.5 \mathrm{ml} . / \mathrm{kg}$. body weight. Homologous A.T.S. 50 units $/ \mathrm{kg}$. body weight.

because the mortality in group $\mathrm{V}$, which received 50 units of antitoxin, was $100 \%$ at the fourteenth day. However, this tenfold decrease in the dose of A.T.S. did interfere with the rate of immune response to toxoid-for example, compare the immune status of groups I and II at 14 days.

In order to confirm this relationship serum antitoxin levels were measured in rabbits following the injection of homologous A.T.S. with toxoid, at one-tenth the dose of heterologous A.T.S., namely 50 units $/ \mathrm{kg}$. body weight. The advantage of this procedure lay in the fact that the small dose of homologous A.T.S. persists in serum for almost 4 weeks at a detectable level (Table 5).

The results using fluid and adsorbed toxoids are illustrated in Figs. 5 and 6 
respectively. While there was still a measurable interference of the immunogenic action of fluid toxoid (Fig. 5) it will be seen that with adsorbed toxoid an uninterrupted immune reaction was obtained (Fig. 6).
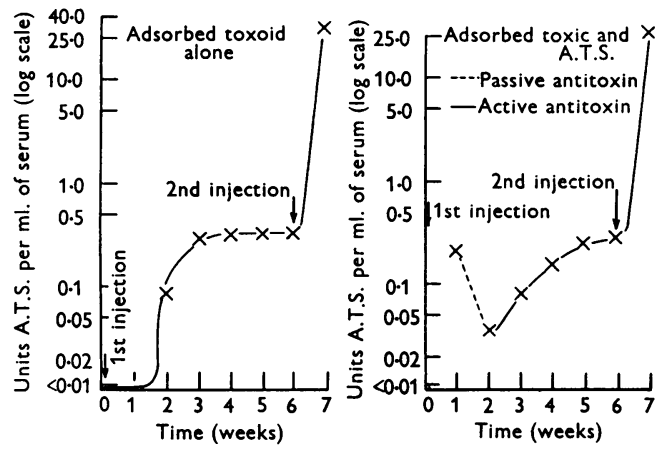

Fig. 6. Non-interference of primary immune response by simultaneous injection of A.T.S. Dose: adsorbed toxoid $0.5 \mathrm{ml} . / \mathrm{kg}$. body weight. Homologous A.T.S. 50 units $/ \mathrm{kg}$. body weight.

\section{DISCUSSION}

The object of this work has been to throw some light on those aspects of tetanus immunization which are directly concerned with the management of the injured person. First, we have been able to test certain assumptions on passive immunization which have been decided from evidence in diphtheria immunotherapy. Secondly, it was thought worth while to reaffirm some facts concerned with active immunization which, in the course of time, appear to have been overlooked by clinicians today. And finally, we have been able to show, for the first time, the potential value of homologous tetanus antitoxin as a prophylactic agent.

Dealing with the first of these problems, Glenny \& Hopkins (1922, 1923), working with diphtheria antitoxin prepared in horses, showed that sensitized rabbits eliminated the antitoxin more rapidly than normal animals. Similar results have been recorded by Talmage, Dixon, Bukantz \& Dammin (1951) and, Dixon, Bukantz, Dammin \& Talmage (1951) using ${ }^{131}$ I-labelled serum proteins. On the basis of these data and some isolated observations on individual patients who received tetanus antitoxin (Sacquépée \& Jude, 1937; Ramon, Boivin, Richou, Djourichitch \& Maccolini, 1938; Barr \& Sachs, 1955), it is now generally thought that persons with a previous experience of horse serum will eliminate A.T.S. very much more rapidly than normal persons. In fact, Wright (1958) attributed the failure of A.T.S. in a fatal case of tetanus to this phenomenon.

The findings reported here support the general view that sensitized animals eliminate A.T.S. more rapidly than normals. This can be shown particularly when the relatively low serum levels following subcutaneous injection are compared (Table 2). When the A.T.S. is given intravenously and very high serum levels obtained the rate of elimination by normal and sensitized animals is indistinguishable (Table 1). What is worth underlining in the results reported in Tables 1 and 2 is the profound drop in A.T.S. serum level in both normal and sensitized at the 
end of 7 days. This we feel is of far greater significance clinically than the slight differences exhibited by the two groups.

Our results with humans passively immunized with 1500 units horse A.T.S. subcutaneously are of interest. Serum assays in paired blood samples taken mainly 2 and 7 days after injection show that the antitoxin levels in normal (Table 7) and sensitized (Table 8) persons were indistinguishable. It would appear that the very rapid elimination of horse A.T.S. in man, as in animals, is somewhat unpredictable and is not greatly influenced by previous experience with horse serum (Table 9). Thus, the risk of tetanus 'post-serique' (Wright, 1958) is faced not only by individuals with a previous experience of horse serum but also by those without such experience.

The value of active immunization against tetanus is accepted without question, but the value of combined active and passive immunization in the treatment of non-immune subjects following injury is less clear. Broadly speaking it has been found that A.T.S. masks the primary immune response to fluid toxoid (Ramon \& Laffaile, 1925; Cooke \& Jones, 1943; Barr \& Sachs, 1955) while this effect does not occur, or only partially, with adsorbed toxoid (Gold \& Bachers, 1943; Ericsson, 1948; Eckmann, 1959). Ramon and his co-workers have repeatedly claimed effective immune response with the combined immunization of A.T.S. and fluid toxoid (Ramon \& Zoeller, 1926, 1927; Ramon et al. 1938; Ramon, Kourilsky, Richou \& Kourilsky, 1939). It might be noted that these workers used toxoid at weekly intervals and doses up to $5 \mathrm{ml}$. Enquiries at leading hospitals in Australia revealed that combined active-passive immunization was often used for the treatment of non-immune patients. Clearly, this procedure required re-investigation.

Our experimental results in this connexion are summarized in Tables 11 and 12 and Figs. 2-4. They show that, in different animal species and with different standards of measurement, there was a complete, or almost complete, masking of the primary immune response to fluid toxoid by A.T.S. With adsorbed toxoid the masking was detectable but not complete. As one increased the antitoxin/ toxoid ratio the interference became more profound. It is quite obvious that the simultaneous use of antitoxin and fluid toxoid (even in different limbs) is immunologically unsound. To a lesser degree this also applies to the adsorbed toxoid. However, the masking can be largely overcome by delaying the injection of adsorbed toxoid by 7 or more days (Table 11 and Fig. 4). In passing, it might be noted that active antitoxin response to adsorbed toxoid is far better (rate and concentration) than that obtained with a similar dose of fluid toxoid.

Finally, we have investigated the behaviour of homologous antitoxin in rabbits, guinea-pigs and humans. It is an accepted fact that passive immunity induced by homologous serum lasts longer than one produced by heterologous serum at the same dose. The behaviour of tetanus antitoxin is no exception to this generalization. We have shown that the passive antitoxin level in rabbits is consistently higher following homologous antitoxin even though the dose given was only onetenth that of the heterologous serum (Fig. 1). In guinea-pigs it could be demonstrated that the degree of protection afforded by $2.5 \mathrm{units} / \mathrm{kg}$. body weight offered better protection against tetanus toxin than 250 units $/ \mathrm{kg}$. of heterologous A.T.S. 
(Table 6). In human volunteers of an average weight of $70 \mathrm{~kg}$. it was shown that a dose of 200 units of homologous A.T.S. gave serum levels of $0.02 \mathrm{unit} / \mathrm{ml}$. in five out of seven persons for at least 21 days (Table 10). In fact, antitoxin was still detectable 8 weeks after injection.

These results provide a strong argument for considering the use of homologous A.T.S. in selected cases, particularly hypersensitive individuals. The concentrate from selected immune sera (10-50 units $/ \mathrm{ml}$.) would contain $100-500 \mathrm{units} / \mathrm{ml}$. Our figures suggest that a prophylactic adult dose of homologous A.T.S. would be of the order of 200-250 units and for children proportionately less.

A further advantage that can be demonstrated for homologous A.T.S. is concerned with combined active-passive immunization. Since homologous serum can be used in low doses, in contrast to the high doses required for heterologous serum, the interference with the primary immune response to adsorbed toxoid is almost absent. This is well shown in our mouse protection tests (Table 12) or by the serum assay in rabbits (Fig. 6). The case for low dosage homologous antitoxin for human use thus appears to be established.

\section{SUMMARY AND CONCLUSIONS}

1. A study of the various aspects of passive tetanus immunization and combined active and passive immunization in different animal species has been undertaken.

2. The criteria on which conclusions have been based consisted of titration of antitoxin serum levels and mouse and guinea-pig protection tests using a challenge of 20 M.L.D. of tetanus toxin.

3. A study of the rate of elimination of heterologous tetanus antitoxin in normal and sensitized animals showed that the latter eliminated antitoxin more rapidly from circulation after subcutaneous injection but no difference could be detected following intravenous administration. More important is the profound loss of serum antitoxin in both animal groups from the seventh day onwards.

4. The rate of elimination in humans receiving 1500 units of horse antitoxin subcutaneously was approximately the same in normal subjects and those who had been previously exposed to horse serum.

5. The interference of an active primary immune response by the simultaneous injection of antitoxin in rabbits was consistently more marked with fluid toxoid than with adsorbed toxoid. Thus, combined active and passive immunization of persons who have never been actively immunized, is not recommended, especially with fluid toxoid.

6. Administration of adsorbed toxoid 7 days or more after passive immunization with heterologous antitoxin does not interfere with the primary immune response.

7. Comparison of the immunizing potency in rabbits of fluid and adsorbed toxoids showed that the latter was far superior.

8. Homologous antitoxin was demonstrated in man and animals to be immunologically superior to the heterologous type in every respect. It persisted unchanged in a therapeutically active concentration for at least 3 weeks in humans and its 
protective action in guinea-pigs was at least 100 times greater than heterologous antitoxin. Since homologous antitoxin can be used in low doses it will not interfere with the primary immune response in combined immunization.

9. A recommended prophylactic dose of homologous antitoxin for man would be $200-250$ units.

The authors wish to express their sincere thanks to the Director, Dr P. L. Bazeley, and staff of the Commonwealth Serum Laboratories, Melbourne, for providing laboratory facilities, animals and valuable discussion during the entire course of this work. Without such assistance this work could not have been undertaken with the facilities available at our University.

We also wish to thank most sincerely Dr J. W. Hill, Medical Superintendent of Ballarat Base Hospital, for arranging the trial of homologous A.T.S. in humans and for supplying most of the serum specimens for our studies of A.T.S. levels in man. We are also indebted to Dr G. T. Archer, Assistant Director of the N.S.W. Blood Transfusion Service, Sydney, for supplying immune human sera and to the Colombo Plan Organization for financial support of one of us (J.C.S.).

\section{REFERENCES}

BArR, M. \& SAChs, A. (1955). Army Pathology Advisory Committee : report on 'The investigation into the prevention of tetanus in the British Army'. War Office.

Cooke, J. V. \& Jones, F. G. (1943). The duration of passive tetanus immunity and its effect on active immunization with tetanus toxoid. J. Amer. med. Ass. 121, 1201.

Dixon, F. J., Bukantz, S. C., Dammin, G. J. \& Talmage, D. W. (1951). Fate of $I^{131}$ labelled bovine gamma globulin in rabbits. Fed. Proc. 10, 553.

Eckmann, L. (1959). Die Gleichzeitige Anwendung von Serum und Toxoid in der Tetanus Prophylaxe. Schweiz. Med. Woch. 89, 311.

Ericcson, H. (1948). Studies on tetanus prophylaxis. J. clin. Path. 1, 306.

Gardner, P. A. (1960). Tetanus immunization. Brit. med. J. i, 1277.

Glenny, A. T. \& Hopkins, B. E. (1922). Duration of passive immunity. Part I. J. Hyg., Camb., 21, 142.

Glenny, A. T. \& Hopkins, B. E. (1923). Duration of passive immunity. Part III. J. Hyg., Camb., 22, 37.

Glenny, A. T. \& Stevens, M. F. (1938). The laboratory control of tetanus prophylaxis. J. R. Army Med. Corps, 70, 308.

Gold, H. \& BACHERS, H. (1943). Combined active-passive immunization against tetanus. J. Immunol. 47, 335.

Hunter, W. F. (1959). Tetanus prophylaxis. Med. J. Aust. ii, 98.

IPSEN, J. (1952). The effect of environmental temperature on the immune response of mice to tetanus toxoid. J. Immunol. 69, 273.

Littlewood, A. H. M., Mant, A. K. \& Wright, G. Payling (1954). Fatal tetanus in a boy after prophylactic tetanus antitoxin. Brit. med. $J$. ii, 444.

Madigan, M. R. (1957). Prophylactic value of tetanus antitoxin. Brit. med. J. i, 706.

Parish, H. J. (1958). Antisera, Toxoids and Vaccines, 4th ed. Edinburgh: E. and S. Livingstone Ltd.

Ramon, G., Boivin, A., Richou, R., Djourichitch, M. \& Maccolini, R. (1938). La sèroanatoxithèrapie des toxi-infections en èvolution ses bases expèrimèntals. Rev. d'Immunol., Paris, 4, 24.

Ramon, G., Kourilsky, R., Richou, R.\& Kourilsky, S. (1939). Recherches immunologiques sur la sèro-anatoxithèrapie tétanique. Rev. d'Immunol., Paris, 5, 432.

Ramon, G. \& Lafaille, A. (1925). Sur l'immunisation antitétanique. C.R. Soc. Biol., Paris, 93, 582. 
Ramon, G. \& Zoeller, C. (1926). L'immunité et antitétanique par l'anatoxine chez l'homme. Pr. Med. 31, 485.

Ramon, G. \& Zoeller, C. (1927). L'anatoxine tétanique et l'immunisation active de l'homme vis-à-vis du tétanos. Ann. Inst. Pasteur, 41, 803.

SaCquépée, E. \& Jude, A. (1937). Sur la valeur et la durée de l'immunité antitétanique après injection de rappel, chex l'homme immunisé. C.R. Soc. Biol., Paris, 125, 711.

Talmage, D. W., Dixon, F. J., Bukantz, S. C. \& Dammin, J. G. (1951). Antigen elimination from the blood as an early manifestation of the immune response. J. Immunol. 67, 243.

Wadsworth, A. B. (1947). Standard Methods. Baltimore: Williams and Wilkins Co.

Wright, G. Payling (1958). The use of A.T.S. in the treatment and prophylaxis of tetanus. Proc. R. Soc. Med. 51, 997. 